\title{
Cost Benefit Analysis of Air Pollution Abatement Options in the Ger Area, Ulaanbaatar, and Health Benefits Using Contingent Valuation
}

\author{
O. Enkhtsolmon, T. Matsumoto, and Erkhembayar Tseveen
}

\begin{abstract}
We conducted a cost-benefit analysis of air pollution abatement options that considered income level by region in a residential sector of a ger area in Ulaanbaatar, Mongolia. The study selected three feasible measures, taking into account direct benefits (fuel savings), health benefits and investment costs. The net present value of the abatement combined options and the reduction of total suspended particulate (TSP) emissions during the investment timeframe were estimated. We also conducted double-bounded dichotomous contingent (DBDC) valuation surveys with 373 respondents to gather data on air pollution awareness and willingness to pay (WTP) for protection of health from air pollution. To assess the unit costs of health benefits, we relied on the willingness-to-pay study carried out as part of the CVM study, which derived a value of WTP of US\$20.30, which is the value placed on protection of health from air pollution.

As for the results, the air pollution abatement combined option can be seen to reduce emissions approximately 50 percent in Ulaanbaatar over 7 years.
\end{abstract}

Index Terms-Air pollution, cost-benefit analysis, contingent valuation, Ulaanbaatar.

\section{INTRODUCTION}

Ulaanbaatar faces an air pollution problem, particularly during the winter months, and the pollution has several negative effects on human health. Currently, 60 percent of Ulaanbaatar's population lives in the ger ${ }^{1}$ areas, and the proportion is growing. Ger area heating systems burn continuously during the winter season and their contribution to the overall air pollution level then reaches 70 percent and more in the ger areas and up to 60 percent in the city center. The residents of these areas use coal-fired stoves for both heating and cooking. Because ger area residents have no access to the district heating system, they have to depend on their own heating systems. The average households consumed about $4 \mathrm{t}$ of raw coal and $3.18 \mathrm{t}$ of wood during the heating season. Particulate matter $\mathrm{PM}_{10}$ and $\mathrm{PM}_{2.5}$ concentrations in

Manuscript received May 19, 2015; revised July 20, 2015.

O. Enkhtsolmon and T. Matsumoto are with the Department of Environmental Engineering, University of Kitakyushu, Fukuoka 8080135, Japan (e-mail: u3dac001@eng.kitakyu-u.ac.jp, matsumoto-t@kitakyu-u.ac.jp).

Erkhembayar Tseveen is with School of Applied Science, Mongolian University of Science and Technology, Ulaanbaatar, Mongolia (e-mail: erkhem_1@must.edu.mn).

${ }^{1}$ Traditional gers are nomadic felt tents with wooden lattice substructures, used by Mongolian nomads for centuries. The ger was an ideal living solution for nomads for so long because it is mobile, light-weight, and portable, making it well suited for easy moving.
Ulaanbaatar are 3 to 6 times greater than Mongolian air quality standards (AQS), and annual average concentrations are $75 \sim 150 \mu \mathrm{g} / \mathrm{m}^{3}$ and $150 \sim 250 \mu \mathrm{g} / \mathrm{m}^{3}$, which is 7 to 15 times higher than the WHO standard ratio, and these are among the highest measured values recorded in any world capital (Table I, Table II).

TABLE I: ANNUAL AVERAGE PM CONCENTRATION OF ULAANBAATAR 2008.06-2009.05 [1]

\begin{tabular}{|c|c|c|c|c|}
\hline \multirow{2}{*}{ Location } & \multirow{2}{*}{$\begin{array}{c}\text { PM10 } \\
\left(\mu \mathrm{g} / \mathrm{m}^{3}\right)\end{array}$} & \multirow{2}{*}{$\begin{array}{l}\text { PM2.5 } \\
\left(\mu \mathrm{g} / \mathrm{m}^{3}\right)\end{array}$} & \multicolumn{2}{|c|}{ Exceedance ratio to AQS } \\
\hline & & & Mongolia & WHO \\
\hline $\begin{array}{c}\text { Central city } \\
\text { areas }\end{array}$ & $150-250$ & $75-150$ & $3-6$ & $7-15$ \\
\hline Ger areas & $350-700$ & $200-350$ & $7-14$ & $17-35$ \\
\hline
\end{tabular}

TABLE II: MONGOLIAN AIR QUALITY STANDARDS AND WHO AIR QUALITY

\begin{tabular}{|c|c|c|c|c|}
\hline \multicolumn{2}{|c|}{ Pollutant } & Average time & $\begin{array}{l}\text { Mongolia AQG } \\
\text { value }\left(\mu \mathrm{g} / \mathrm{m}^{3}\right)\end{array}$ & $\begin{array}{c}\text { WHO AQG } \\
\text { value } \\
\left(\mu \mathrm{g} / \mathrm{m}^{3}\right)\end{array}$ \\
\hline \multirow{4}{*}{$\begin{array}{l}\text { Sulfur } \\
\text { dioxide }\end{array}$} & \multirow{4}{*}{$\mathrm{SO}_{2}$} & 10 mins & 500 & 500 \\
\hline & & 20 mins & 450 & \\
\hline & & 24 hours & 20 & 20 \\
\hline & & 1 year & 10 & \\
\hline Ozone & $\mathrm{O}_{3}$ & 8 hours & 100 & 100 \\
\hline \multirow{2}{*}{$\begin{array}{l}\text { Particulate } \\
\text { matter }\end{array}$} & \multirow{2}{*}{$\mathrm{PM}_{10}$} & 24 hours & 100 & 50 \\
\hline & & 1 year & 50 & 20 \\
\hline \multirow{2}{*}{$\begin{array}{l}\text { Particulate } \\
\text { matter }\end{array}$} & \multirow{2}{*}{$\mathrm{PM}_{2.5}$} & 24 hours & 50 & 25 \\
\hline & & 1 year & 25 & 10 \\
\hline
\end{tabular}

We conducted cost-benefit analysis (CBA) for the air pollution abatement combined options. This study targeted air pollutant abatement options for the major source of coal fired stoves in the ger area, Ulaanbaatar.

\section{METHODS}

We conducted a cost-benefit analysis of air pollution abatement options in a residential sector of the ger area considering income level by region. The combined various abatement options included relocation of ger area households into apartments, using electric heaters instead of coal stoves, and installing central heating systems.

We also conducted a double-bounded dichotomous choice (DBDC) contingent valuation (CV) survey with 373 respondents in October 2014 and collected complete information on air pollution awareness and respondents willingness to pay for protection of health from Air pollution The survey was designed to collect data from a representative sample of respondents which living in the ger area and the apartment area in the Ulaanbaatar. 
In addition, $\mathrm{CBAs}$ were conducted by comparing the costs such as investment costs of the measures and benefits such as health benefits. In order to estimate the health benefits obtained from willingness-to-pay (WTP), a study was carried out as part of the $\mathrm{CV}$, and the emissions reductions were estimated by using the reductions in fuel consumption [3].

\section{QUESTIONNAIRE SURVEY}

\section{A. Survey Design}

Pretest and pilot tests were conducted to assess the effectiveness of the survey. A pretest was conducted in September 2014 at Mongolian Science and Technology University. 40 students were interviewed in a pilot test which focused on the content of the WTP questions. The questionnaire consisted of three parts. The first section contained air pollution awareness questions, including queries about the current air pollution situation in Ulaanbaatar, understanding of PM2.5 and the relationship between PM2.5 and health, respiratory diseases and expenditures on treatment of these diseases, and understanding of the N95 standard mask for protecting health against PM2.5. The second part consisted of the contingent valuation survey. The final section contained socio-economic questions, including those relating to the gender, age, housing type, occupation, family size, and household income.

A final survey was conducted in October 2014. Questionnaire sheets were distributed and later collected by elementary school students, and questions were responded to by adults. Four elementary schools were randomly selected which are located in the ger area or the city center of Ulaanbaatar.

Our explanation involves three elements: 1) explanations about particulate matter (PM2.5) and health damages caused by PM2.5, and current concentrations of PM2.5 in Ulaanbaatar, 2) respondents' willingness to pay (WTP) for protection of health from particulate matter(PM2.5), and 3) payment objective and method.

The respondents were asked the following double-bounded dichotomous choice (BDDC) questions:

Air pollution abatement projects will be reducing Ulaanbaatar air pollution by 50\% from 2014 to 2020. During the 7 years you need to protect your family health from air pollution. If you use a N95 standard mask it can protect your health from particulate matter (PM2.5) by more than $60 \%$. Are you willing to pay some amount of money during the winter months (November to March) to protect your family's health from air pollution? You would have to pay this amount for 7 years.

Would you pay US\$16.40 a month?

(1) Yes (2) No

If you answered yes to the first question, would you pay US\$ 54.80 a month?

\section{(1) Yes (2) No}

If you answered no to the first question, would you pay US\$ 8.20 a month?

(1) Yes (2) No

TABLE III: DESCRIPTION OF THE INDEPENDENT VARIABLES, AND THE MEAN AND STANDARD DEVIATION (S.D.) OF THE RESPONSES

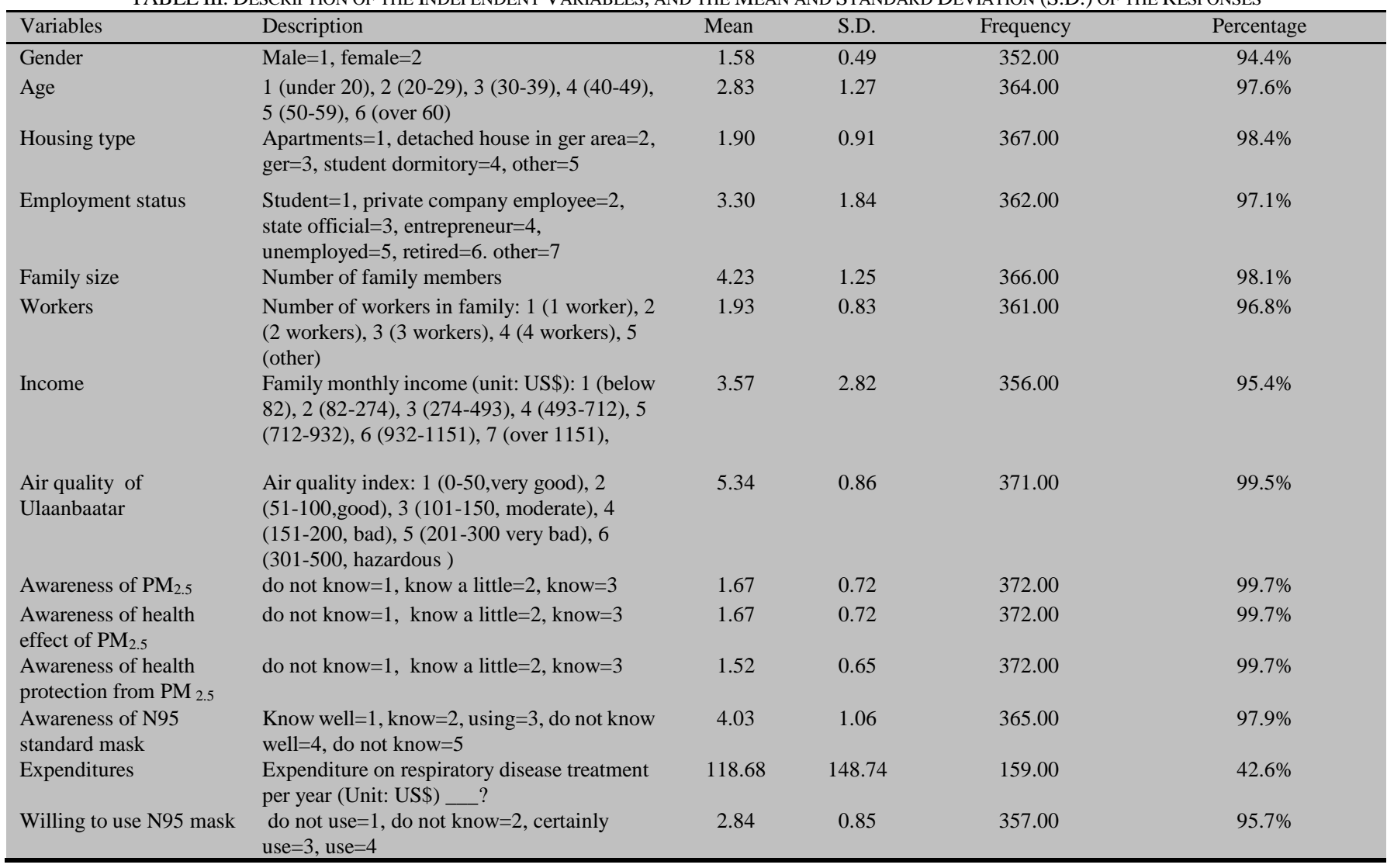

\section{B. Methods and Results}

In our study, the survey presented was well received, with a response rate of $93.3 \%$ (373/400). $2.7 \%$ of respondents did 
not answer the WTP questions.

The background and validity checking questions used in this study are listed in Table III. Detailed descriptions of the variables are also given in Table III. These variables include the respondent's demographic characteristics, socio-economic status, and the air pollution status in their resident areas from a subjective perspective.

The average age of respondents was from 30 to 39 years old. The mean household monthly income of respondents participating in our survey was about US\$493, compared to the average household monthly income of US\$579 in 2013, Statistics Department of Ulaanbaatar [4]. The percentage of respondents by housing type was apartment $40.2 \%$, detached house in ger area $32.7 \%$, ger $22.3 \%$, and other $4.8 \%$. The percentage of respondents' valuation for air quality of Ulaanbaatar was hazardous $53.4 \%$, very bad $31.1 \%$, bad $11 \%$, and moderate $3.5 \%$.

\section{Estimation of WTP}

In Table IV, the results of the WTP responses to the valuation questions can be seen, where the value is presented in US\$ per month.

The dichotomous choice contingent valuation surveys can be improved by asking each respondent a second dichotomous choice question which depends on the response to the first question - if the first response is "yes," the second bid is some amount greater than the first bid; while if the first response is "no," the second bid is some amount smaller [5].

The data was used to survey Ulaanbaatar residents regarding their willingness to pay to protect their family's health from air pollution using N95 masks until air quality has improved.

TABLE IV: RESULTS OF THE WTP RESPONSES

\begin{tabular}{|c|c|c|c|c|c|c|c|}
\hline & \multicolumn{3}{|c|}{ Bound on WTP (US\$) } & \multicolumn{4}{|c|}{ Responses to DBDC questions } \\
\hline & $\mathrm{T} 1$ & $\mathrm{TU}$ & $\mathrm{TL}$ & Yes-Yes (YY) & Yes-No (YN) & No-Yes (NY) & No-No (NN) \\
\hline Group1 & 16.4 & 54.8 & 8.2 & 9 & 30 & 17 & 24 \\
\hline Group2 & 11.0 & 27.4 & 5.5 & 13 & 20 & 9 & 19 \\
\hline Group3 & 13.7 & 21.9 & 4.4 & 19 & 18 & 28 & 17 \\
\hline Group4 & 19.7 & 32.9 & 9.9 & 29 & 43 & 31 & 37 \\
\hline
\end{tabular}

T1 represents the amounts presented the first time, TU the higher amounts presented the second time, and TL the lower amounts presented the second time. Estimation of WTP was calculated by the CVM double-bound of log-linear logit model using CVM.xsl version4 [6].

These results showed that $97 \%$ of respondents were able to express a positive WTP, and that average WTP was US\$20.30 per household, per month. It would be payed during the highly polluted 5 months of the year. Estimated average value of WTP is shown in Table V.

TABLE V: RESULTS FOR WTP

\begin{tabular}{|c|c|c|c|c|}
\hline \multicolumn{3}{|c|}{ Estimation result } & \multicolumn{2}{|c|}{ Estimated WTP US\$ } \\
\cline { 1 - 2 } Variable & Coefficient & $\mathrm{t}$ value & \multirow{2}{*}{$\begin{array}{c}\text { Median } \\
\text { value }\end{array}$} & 14.35 \\
\cline { 1 - 2 } constant & 4.12 & 15.78 & Average & 20.30 \\
\cline { 1 - 2 } $\ln ($ Bid) & -1.55 & -16.14 & & \\
\cline { 1 - 3 }$n$ & 363.00 & & & \\
\hline Log likelihood & -507.05 & & & \\
\hline
\end{tabular}

\section{COST BENEFIT ANALYSIS}

\section{A. Introduction}

We conducted a cost-benefit analysis of air pollution abatement options in the ger area of Ulaanbaatar (UB) considering income level by region. Abatement options included 1) ger area household's relocation into an apartment, 2) using electric heating, and 3) installing a central heating system.

Detailed descriptions of abatement options from 2014 to 2020 are shown in Table VI.

The city consists of two main areas: the city center, with high-rise office and apartment buildings, and the surrounding ger areas, with mainly low-rise one story detached houses and gers [7]. In this survey, the ger area was divided into three parts by region and income level: city center ger area close to the city, residential middle-income households, mid-tier ger area residential low-income households, and fringe ger area residential lowest income households [8].

TABLE VI: DESCRIPTION OF ABATEMENT OPTIONS BY YEAR

\begin{tabular}{|c|c|c|c|}
\hline & $\begin{array}{c}\text { Option 1: } \\
\text { Number of } \\
\text { households } \\
\text { relocating into } \\
\text { apartments }\end{array}$ & $\begin{array}{c}\text { Option 2: } \\
\text { Number of } \\
\text { households using } \\
\text { electric heaters }\end{array}$ & $\begin{array}{c}\text { Option 3: Number of } \\
\text { households installing } \\
\text { central heating } \\
\text { systems }\end{array}$ \\
\hline 2014 & 4,924 & 16,000 & 2,500 \\
\hline 2015 & 10,650 & 17,000 & 2,500 \\
\hline 2016 & 12,307 & 16,000 & 2,500 \\
\hline 2017 & 13,774 & 16,000 & 2,500 \\
\hline 2018 & 8,382 & 20,000 & 2,500 \\
\hline 2019 & 3,200 & 19,000 & 2,500 \\
\hline 2020 & 5,847 & 20,769 & 2,500 \\
\hline & 59,084 & 124,769 & 17,500 \\
\hline
\end{tabular}

Currently 184,229 households (60\% of Ulaanbaatar's population) live in the ger areas, $54.5 \%$ in small detached houses, and $44.3 \%$ in gers.

Option (1) applies to 59,084 households which are in the city center and ger area relocation into apartments, and can be considered a ger area housing plan project.

Option (2) applies to 124,769 households living in mid-tier and fringe gers beginning to use electric heaters instead of coal stoves. If electric heaters were supplied in the ger area, it would increase electricity demand. Therefore, we analyzed the costs for combined measures, including electric heaters and wind power generation in the first Mongolian implementation project.

Option (3) applies to 17,500 households living in small detached houses in the mid-tier ger area and would involve installation of central heating systems.

\section{B. Estimation of Pollutant Emissions Reductions}


Annual average fuel consumption of ger area households was $3.49 \mathrm{t}$ of coal and $3.27 \mathrm{t}$ of wood when using ger stoves, and $4.49 \mathrm{t}$ of coal and $2.99 \mathrm{t}$ of wood when using wall stoves. These estimates are based on the number of households reducing fuel consumption through abatement options. Emission reductions were calculated using the following calculations. Ger area households fuel consumption and emission factors are shown in Table VII. Estimated TSP, $\mathrm{PM}_{10}, \mathrm{SO}_{\mathrm{X}}$, and $\mathrm{NO}_{\mathrm{X}}$ emissions reductions from abatement measures compared to BAU are shown in Fig. 1. Emission reductions were calculated using the following formula:

Emission reductions $=$ Coal reduction $(t) \times$ coal emission factor $(\mathrm{kg} / \mathrm{t}) / 1,000+\operatorname{wood}$ reduction $(t) \times$ wood emission $(\mathrm{kg} / \mathrm{t}) / 1,000$

TABLE VII: HOUSEHOLD FUEL CONSUMPTION AND EMISSION FACTORS [9]

\begin{tabular}{|c|c|c|c|c|c|c|c|}
\hline & \multicolumn{2}{|c|}{ Fuel usage (t/year) } & \multicolumn{5}{|c|}{ Emission factor $(\mathrm{kg} / \mathrm{t})$} \\
\hline & $\begin{array}{c}\text { Ger } \\
\text { stove }\end{array}$ & $\begin{array}{c}\text { Wall } \\
\text { stove }\end{array}$ & $\mathrm{TSP}$ & $\mathrm{PM}_{10}$ & $\mathrm{SO}_{\mathrm{X}}$ & $\mathrm{NO}_{\mathrm{X}}$ & $\mathrm{CO}$ \\
\hline Coal & 3.49 & 4.49 & 5.4 & 3.3 & 7.5 & 2.4 & 173.34 \\
\hline Wood & 3.27 & 2.99 & 3.82 & 3.82 & 0.008 & 1.2 & 69.2 \\
\hline
\end{tabular}

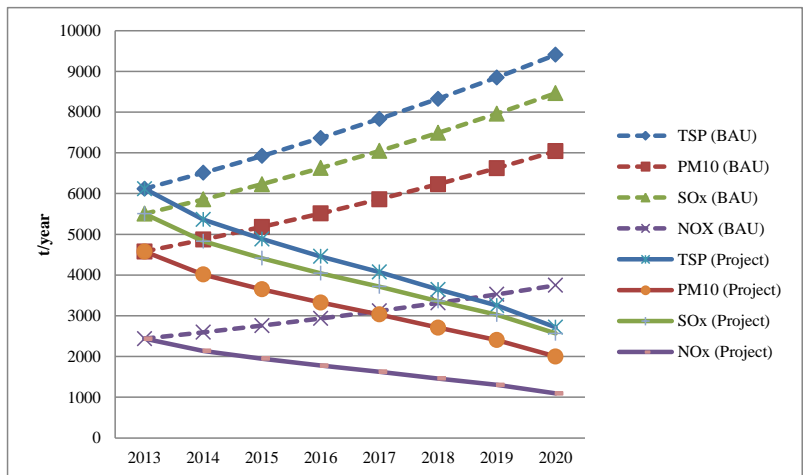

Fig. 1. Emission reductions by abatement options compared to BAU.

\section{Estimation of Health Benefits}

To assess the unit costs of health benefit, we relied on the willingness-to-pay study carried out as part of the CVM study, which derived a value of WTP of US\$20.30, which is the value placed on protection of health from air pollution.

Respondents were willing to pay this amount for protecting their family's health from air pollution over 7 years, when Ulaanbaatar air pollution will have been reduced $50 \%$.

Cost benefits were calculated using the following formula:

Cost benefit $=$ Number of households in year $t \times \mathrm{WTP}$ value $\times 5$ month (highly polluted seasons)

\section{Estimation of Costs and Benefits}

Net present value (NPV) of the cost is the initial investment in the pollution abatement options, and the benefit is the cost savings achieved through health protection WTP value [10], [11].

A 7 -year timeframe was assumed with $13 \%$ discount rate [12] for all calculations.

$N P V$ is expressed by Equation (1).

$$
N P V=\sum_{t=1}^{n} \frac{B t-C t}{(1+r)^{t}}
$$

$B t$ is the benefit in year $t, C t$ is cost in year $t$, and $r$ is the discount rate.

\section{E. Results of Cost-Benefit Analysis}

The net present value (NPV) of air pollution abatement combined options and each of the abatement options, the investment cost and the 7-year average emission reductions are shown in Table VIII.

NPV of the combined options was estimated at US\$-1499.73 million.

TABLE VIII: RESULTS OF COST BENEFIT ANALYSIS

\begin{tabular}{|c|c|c|c|c|c|}
\hline \multicolumn{2}{|l|}{ 2014-2020 } & $\begin{array}{c}\text { Option 1: relocation } \\
\text { into apartment }\end{array}$ & $\begin{array}{c}\text { Option 2: use of electric } \\
\text { heaters } \\
\end{array}$ & $\begin{array}{c}\text { Option 3: installing } \\
\text { central heating system }\end{array}$ & Combined options \\
\hline \multirow{2}{*}{ Emission reduction (\%) } & average & $13 \%$ & $22 \%$ & $5 \%$ & $41 \%$ \\
\hline & $\max$ & $23 \%$ & $42 \%$ & $7 \%$ & $72 \%$ \\
\hline \multirow{4}{*}{ Total emission reduction $(\mathrm{t})$} & TSP & 8620 & 14941 & 3259 & 26820 \\
\hline & $\mathrm{PM}_{10}$ & 6341 & 11446 & 2398 & 20185 \\
\hline & $\mathrm{SO}_{\mathrm{x}}$ & 8144 & 12492 & 3079 & 23716 \\
\hline & $\mathrm{NO}_{\mathrm{X}}$ & 3471 & 5864 & 1313 & 10648 \\
\hline$\$$ per $t$ reduction & TSP & 243994 & 33320 & 7479 & 97890 \\
\hline \multicolumn{2}{|c|}{ Investment costs US\$ millions } & 2103 & 498 & 24 & 2625 \\
\hline \multicolumn{2}{|c|}{ Number of households } & 59084 & 124769 & 17500 & 201353 \\
\hline \multicolumn{2}{|c|}{ \$ per households } & 35597 & 3990 & 1393 & \\
\hline \multicolumn{2}{|c|}{ Health benefits US $\$$ millions } & \multicolumn{4}{|r|}{301.58} \\
\hline \multicolumn{2}{|c|}{ NPV US\$ millions } & \multicolumn{4}{|r|}{-1499.73} \\
\hline
\end{tabular}

We estimated that TSP and PM10 emissions would be reduced by $26,820 \mathrm{t}$ and $20,185 \mathrm{t}$ respectively and per $t$ reduction of TSP would be US\$97,890. As a result, the combined option average emission reduction was $41 \%$ and reached a maximum of $72 \%$ in the ger area over the 7 years.

Estimated emission reduction for each of the abatement options is shown in Fig. 2.
Option (1), average emission reduction by ger area households relocating into apartments, was $13 \%$, and the maximum reached $23 \%$ in the ger area. The per $t$ reduction of TSP was US\$243,994, highest of the three cases, but the living environment in general can expect a wide range of benefits.

Option (2), average emission reduction by electric heating, 
was $22 \%$, reaching maximum of $42 \%$ in the ger area. The per $t$ of reduction of TSP was US\$33,320.

Option (3), average emission reduction by installing central heating systems, was $5 \%$, reaching a maximum of $7 \%$ in the ger area. The per $t$ reduction of TSP was US\$7,479.

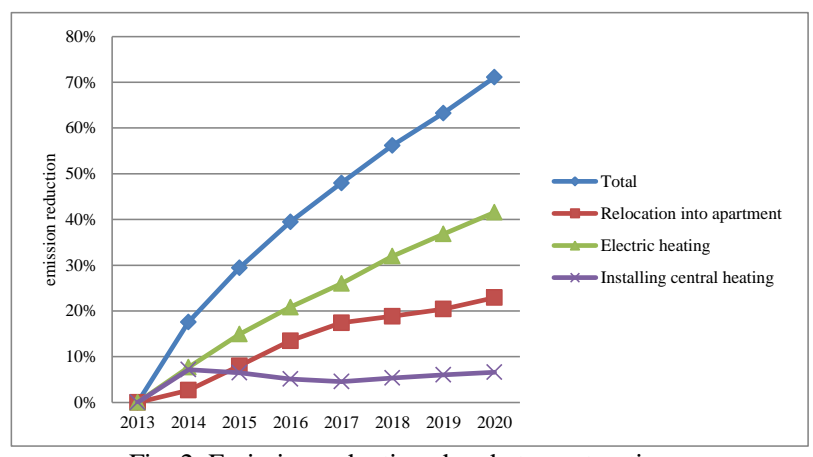

Fig. 2. Emission reductions by abatement options.

\section{CONCLUSION}

In this study, within a relatively short period of time we performed cost-benefit analyses for three feasible measures concerning air pollution in the ger area of Ulaanbaatar.

As for the results, the air pollution abatement combined option can be seen to reduce emissions approximately 50 percent in the Ulaanbaatar over 7 years. Reducing pollution concentrations would prevent illnesses, save lives and avoid enormous health costs.

The monetized health benefit through (DBCD) contingent valuation survey was estimated at 301.58 million US\$ over the 7 years. The CVM results show all respondents expressing good attitudes about their willingness to pay to protect their family's health from air pollution, but they responded negatively that they lacked awareness about health impacts from polluted air and about health protection methods.

The abatement measures to improve air quality were prioritized according to cost benefit analysis and feasibility.

Relocation of ger households into apartments is a long term option. New apartment buildings are established in newly developed areas, and in existing ger areas, but progress is very slow and large scale investment is needed. If there is a possibility of mortgage interest rates becoming cheaper, the housing transfer would increase, this could become an effective measure and the living environment in general could expect a wide range of benefits.

With the use of electric heaters instead of coal stoves in the ger area, emission reduction could be large, assuming that people will actually refrain from using coal once they have obtained an electric heater. Cost of electric heating is significantly higher than the cost of heating with coal, so subsidies would be needed. It would also be necessary to provide large-scale investment to expand power generation capacity.

Ger area households installing central heating systems is a mid-term option, and could reduce emissions at low cost. There would be an increased contribution of emissions from the local heating system, but this is estimated to be small compared to the consumption of coal used for heating in ger stoves. The costs of construction, as well as the incremental capacity needed for local heating, would need to be incorporated in the cost analysis, and these costs would be very high.

\section{REFERENCES}

[1] World Bank, "Air quality analysis of ulaanbaatar improving air quality to reduce health impact," 2011, pp. 21-22.

[2] Mongolian National Standard list. MNS 4587:2007. [Online]. Available: http://www.estandard.mn

[3] World Health Organization, "Guidelines of conducting cost-benefit analysis of household's energy and health interventions," pp. 8-52.

[4] Statistics Department of Ulaanbaatar. [Online]. Available http://ubstat.mn/StatTable $=363$

[5] R. C. M. R. T. Carson, Economic Evaluation of Environmental Quality by CVM, 2001, ch. 8, p. 130.

[6] K. Kuriyama and T. Tsuge, Environmental Assessment Documentation for Beginners, 1st ed., Japan, 2013, ch. 13, pp. 253-265.

[7] World Bank, Mongolia Heating in Poor, Peri-Urban Ger Areas of Ulaanbaatar, Asia Sustainable and Alternative Energy Program, Mongolia, 2009, pp. 13-16.

[8] World Bank, "Enhancing policies and practices for ger area development in Ulaanbaatar, Mongolia,” 2010, pp. 15-22.

[9] The Air Quality Department of the Capital City, Mongolia, Capacity Development Project for Air Pollution Control in Ulaanbaatar City Mongolia, 2012, pp 24-26.

[10] T. Matsuno and T. Yaguchi, Evaluation of Development Projects, Japan: Tsukijichokan, 1999, ch. 2.

[11] Urban Air Quality Management Strategy in Asia, Guidebook, Norwegian Institute for Air Research, Kjeller, Norway and Institute for Environmental Studies, the Free University, Amsterdam, the Netherlands, 2013, pp. 65-69.

[12] Mongolia Central Bank Discount Rate. (December 31, 2012). [Online]. Availavle: http://www.indexmundi.com/mongolia/central_bank_discount_rate.ht $\mathrm{ml}$

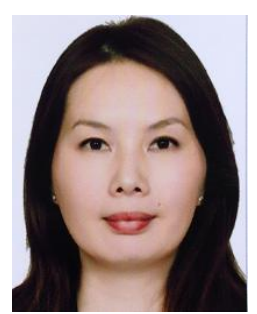

Enkhtsolmon Otgonbayar was born on April 28, 1980 in Japan. She received the degree of master of engineering in environmental engineering, University of Kitakyushu, Japan, 2013. Her thesis was entitled "A study on the efficiency of air pollution control measures in the ger area of Ulaanbaatar, Mongolia based on a field survey". She received the degree of bachelor of science in geo-ecology, Mongolian University of Science and Technology, 2003. Thesis was entitled "Project on geo-environmental survey of the petrol station 'Enkhjin' in Baruun-Urt city of Mongolia.” She was a doctoral student of the Department of Environmental Engineering, University of Kitakyushu, Japan, from 2013.

Toru Matsumoto is a professor of the University of Kitakyushu, Japan. He received his B.A. (1990), M.Eng. (1992) and D.Eng. (1999) from Kyushu University, Japan. He worked as a researcher for Nomura Research Institute (NRI), which is one of the biggest think tanks in Japan, from 1992 until 1995. He was a research associate of Kyushu University from 1995 until 1999 and an associate professor of Kyushu University and the University of Kitakyushu from 2000 until 2008.

Erkhembayar Tseveen is a professor of the School of Applied Science, Mongolian University of Science and Technology. He received his Ph.D. in nuclear physics. He worked as a scientific worker at the Nuclear Research Center of National University of Mongolia, 2000-2008. He was as a radiation protection officer at Areva-Mongolia LLC, 2008-2010. He has been vice director of the School of Applied Science, MUST, since 2012. 